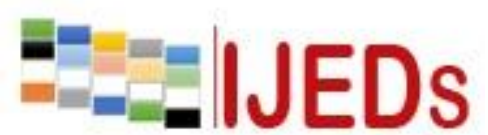

http://ijeds.ppj.unp.ac.id/index.php/IJEDS

\title{
Improving Students' Writing Ability of Descriptive Paragraph and Their Creativity through Picture Word Inductive Model (PWIM) at Second Semester of Non-English Department Students UIN Raden Fatah Palembang
}

\author{
* Elsa Ninda Meifira ${ }^{1}$, Hermawati Syarif ${ }^{2}$ \\ ${ }^{1}$ Graduate Program of Primary Education Faculty of Education Science, Universitas \\ Negeri Padang, Indonesia \\ ${ }^{2}$ PGSD Lecture, FIP, Universitas Negeri Padang, Indonesia \\ Email: budisetiawan5294@yahoo.co.id
}

*Corresponding Author, Received: November 12, 2019, Revised: December 10, 2019, Accepted: December 21, 2019

\begin{abstract}
This study aimed to find out the improvement of students' writing ability of descriptive paragraph through PWIM at second semester of non-English department students in UIN Raden Fatah Palembang. The type of this research was classroom action reseacrh which were conducted in two cycles. Every cycle consisted of five meetings; four meetings to do treatments, one meeting for test. The participations were the second semester of Hadith Science students that consisted of 37 students. This research was analyzed by quantitative data; namely, writing tasks and writing tests. The result from cycle I to cycle II showed that PWIM improved students' writing ability of descriptive paragraph and increased their creativity in writing that could be seen from the activeness and participation of students in the learning process.
\end{abstract}

Keywords: Picture Word Inductive Model, Writing Ability, Descriptive Paragraph.

\section{INTRODUCTION}

Writing is one of the important skills that should be mastered. This skill is needed in all aspects of life, one of them in educational field. It had function to share and express the ideas of the writer through conveying it into paper so that the reader can understand what the writer's intention. Writing involves the application of grammar and the sentence patterns, vocabularies or diction and cross-cultural understanding. Nunan (2003: 88) states that writing is the process of thinking to invent ideas, to express what into good writing, and to arrange the ideas into statement and paragraph clearly. 


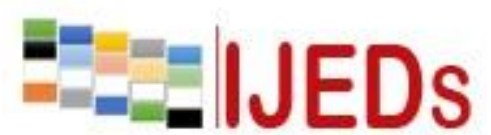

http://ijeds.ppj.unp.ac.id/index.php/IJEDS
International Journal of Educational Dynamics

Vol. 2 No. 1 (pp. 9-14) Desember 2019

p_ISSN 2655-4852

e_ISSN 2655-5093

Process is the important thing in writing especially in educational field . All activities can be seen by this process. It helps the lecturer know whether the students understand about the process. It also facilitates the lecturer to see how far the students able to generate paragraphs and what mistakes they have. Then, in the process of writing, the students can also understand how to write and organize sentences into paragraph well. what the students feel, see, or listen to. However, in this case, many students were confused how to start their descriptive paragraph because of some problems they had in learning English.

Furthermore, in writing descriptive paragraphs, many students had difficulty to write it. Based on the researcher's personal experience as a lecture of English for general course at first year of UIN Raden Fatah, the researcher identified that when the lecturer asked them to make a short descriptive paragraph about the topic given, they tended to mix their local language and English. It was only a few students could do it quite well. It affected the students' score where the score of writing achievement was categorized into middle to low. It was proven when the students wrote paragraph based on the topic given and they got 90 minutes to do that, it was only two students could do it well.

Based on the fact above, the researcher did preliminary. From the preliminary observation, the students had difficulty in paragraph writing. The problem itself came from the students did not know English systematically and they did not understand in using English. It had effect if they wrote paragraph. They got difficulty in finding words to describe object that they wanted to describe. Then, they also found difficulty in finding and arranging their ideas into good paragraph, and time allocation provided was not enough for them in writing. It caused the students could not write this paragraph well.

Futhermore, to be able to create good paragraph writing, especially in language teaching and learning process, creativity was important thing to be gained by students. It influenced the students' writing ability. It was a way to get a new thing, to give interesting ideas, and a potential to look at the relationship for each part. This was the process of original construction and useful ideas as well. Through creativity that they had, students could develop their ideas and their writing was more attractive to read. 


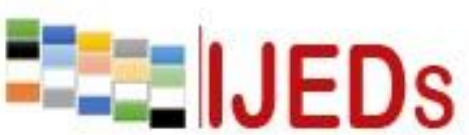

http://ijeds.ppj.unp.ac.id/index.php/IJEDS
International Journal of Educational Dynamics

Vol. 2 No. 1 (pp. 9-14) Desember 2019

p_ISSN 2655-4852

e_ISSN 2655-5093

Creativity was one of the factors that could support students in producing good writing and be a creative writer. Franken (1994: 396) stated that creativity was tendency to generate or recognize ideas, alternatives, or possibilities that may be useful in solving problems, communicating with others, and entertaining ourselves and other. Therefore, creativity was needed to encourage students in writing.

The next problem was English made them confused. Almost a half students said that they did not know the words that they wanted to write in English. It happened because of limitation of vocabularies and lack of background knowledge that they had. They usually got difficulty in how to start writing if the lecturer did not give the list of vocabularies they should use in their sentences. It occured because their experience at school, by the teachers usually gave them list of vocabulary when they asked to write paragraph. Unfortunately, most of them said that they forgot of the list of vocabularies given by their teacher when they were at senior high school.

From the observation, the students could not use their creativity maximaly in writing English paragraphs. It could be seen from the text which was produced when mid semester test where the students often used repeating words and the ideas given was not interested. They said that even they had idea, those lost when they tried to find the words in English because it needed more time to find the words that they took in English. Then, they arranged it into good paragraph. In arranging the sentences into good paragraph, they also found difficulty. They were confused which sentence was put in the first, second, third, and so on in order to become good paragraphs.

Another problem which was found in writing was the grammatical use. The grammatical used here referred to the use of tenses, word classes and sentence elements. The students complained that they could not write text because they did not understand about tenses which always made them confused and sometimes it was the boring part of studying English. Meanwhile, grammar was the main point in writing. As supported by Batstone (1994: 3), the question of how words can (or cannot) be combined in sentences is an important part of grammar, where it is the concern of syntax. On the other words, grammar had function to explain when the writer wrote the text. It was not only how to say thing but also how to arrange words. Therefore, grammar should be understood by the students because it was useful guide in writing paragraph. 


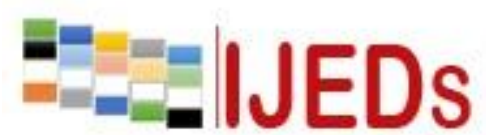

http://ijeds.ppj.unp.ac.id/index.php/IJEDS
International Journal of Educational Dynamics

Vol. 2 No. 1 (pp. 9-14) Desember 2019

p_ISSN 2655-4852

e_ISSN 2655-5093

Based on the facts above, the researcher assumed that one of possible solution to overcome the problems was by using picture word inductive model (PWIM). It was expected to be able to help students in adding their vocabulary, getting ideas even with limited time, not focusing on studying because of classroom situation the researcher mentions before, and understanding about grammatical use. According to Calhoun (1999:v), PWIM is a strategy that uses integrated language arts approach to teaching beginning reading and writing, and it includes the components skills of phonetic analysis, structural analysis, spelling, and mechanics. It could be said that PWIM was a good strategy that could guide students in reading and writing, and students could understand about the components of writing as well.

The statement above was proven by some research that conducted by previous researchers. Sepyanda (2013) did her research to see the effect of PWIM and students' self-efficacy toward their writing skill of descriptive text at grade X SMA. Then, Andriani (2015) conducted her research to find out the use of PWIM strategy to improve students' writing skill of recount text at the eight grade of junior high school 2 Semarang. Next, Nurleli (2018) did her research to know the influence of using PWIM strategy toward students' descriptive text writing ability at the second semester of the eight grade of SMP Al Huda Lampung Selatan. Furthermore, Rosyada (2018) did her research at the sixth semester students of English Education Program to enhance students' critical thinking in developing variety essays as the basic writing through PWIM.

Besides that, this strategy used pictures as media to help students in writing. This would increase and build students' creativity in writing because every student had different point of view in looking at the media. Furthermore, PWIM was model of study which stimulates students' thinking inductively, from the specific thinking to general thinking (see the pictures and words, then made the words and picture available became a sentence then a paragraph) so it was able to guide the students to develop their imagination, creation, and idea to make a sentence or paragraph. Therefore, besides to improve students' writing ability in writing, PWIM can increase students' creativity in writing as well. 


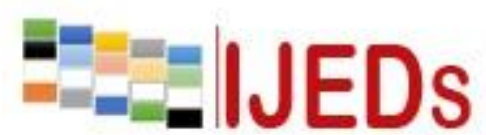

http://ijeds.ppj.unp.ac.id/index.php/IJEDS
International Journal of Educational Dynamics

Vol. 2 No. 1 (pp. 9-14) Desember 2019

p_ISSN 2655-4852

e_ISSN 2655-5093

\section{METHOD}

The type of the research used in this study was classroom action research which aimed to improve classroom teaching and learning process. This research was especially done to improve the students' writing ability and students' creativity in writing. Mettetal (2001:2) stated that classroom action research was a method of finding out what works best in your own classroom so that the teacher could improve students' learning.

The research was conducted at UIN Raden Fatah Palembang. It was Islamic university in Palembang. This university was located on Jl. KH. Zainal Abidin Fikri Km. 3,5 Palembang, South Sumatera. The participants in this study were the second semester of Non-English Department students (students of Ushuluddin and Islamic Thought faculty) of UIN Raden Fatah that consists of 37 students, 18 female and 19 male. The researcher was helped by a collaborator.

In conducting this research the researcher did it i two cycle in which each cycle consisted of five meeting; four meetings for treatments and one meeting for test. The type of data used in this research was quantitative data. The quantitative data was numeric data taken from students' task and test scores in writing descriptive paragraph and in using their creativity in writing.

The researcher analyzed the data of writing descriptive paragraph by using IRMA's scoring rubric (2015:231) to score the students' writing descriptive paragraph that consisted of five indicators; topic sentence, paragraph body, length, grammar and spelling, and closure in which each indicator had range from 1 to 4 with total score 20 points per each indicators. Meanwhile, to score students' creativity, the researcher used the criteria of creativity from Munandar (1981) and categorized the students creativity by range of value of creativity from Anas (2006:453).

\section{RESULTS AND DISCUSSION}

Writing tasks and tests were used to find out the improvement of students' writing ability of descriptive paragraph and their creativity in writing as well. The data of the students' writing ability of decriptive paragraph from precycle stage to cycle II can be seen on the following table: 
B=-EIJEDS

http://ijeds.ppj.unp.ac.id/index.php/IJEDS
International Journal of Educational Dynamics

Vol. 2 No. 1 (pp. 9-14) Desember 2019

p_ISSN 2655-4852

e_ISSN 2655-5093

Table 1. The Results of Students' Writing Ability of Descriptive Paragraph at Precycle, Cycle I, and Cycle II

\begin{tabular}{|c|c|c|c|c|c|c|c|}
\hline \multirow{2}{*}{\multicolumn{2}{|c|}{ Meeting/ Cycle }} & \multicolumn{5}{|c|}{ Indicators of Writing Descriptive Paragraph } & \multirow[b]{2}{*}{$\begin{array}{c}\text { Average } \\
\text { Score }\end{array}$} \\
\hline & & $\begin{array}{c}\text { Topic } \\
\text { Sentence }\end{array}$ & $\begin{array}{c}\text { Paragraph } \\
\text { Body }\end{array}$ & Length & $\begin{array}{c}\text { Grammar } \\
\text { and } \\
\text { Spelling }\end{array}$ & Closure & \\
\hline \multicolumn{2}{|c|}{ Preycle } & 49.5 & 53 & 55 & 54 & 36 & 49.5 \\
\hline \multirow{5}{*}{ Cycle 1} & $\begin{array}{c}\text { Meeting } \\
1\end{array}$ & 45 & 57 & 54 & 52 & 36 & 49 \\
\hline & $\begin{array}{c}\text { Meeting } \\
2\end{array}$ & 57 & 65 & 56 & 60 & 34 & 54.4 \\
\hline & $\begin{array}{c}\text { Meeting } \\
3 \\
\end{array}$ & 62.7 & 66 & 55 & 59 & 33 & 55.2 \\
\hline & $\begin{array}{c}\text { Meeting } \\
4\end{array}$ & 66 & 67 & 56.2 & 59 & 46 & 59 \\
\hline & Test & 69 & 70.1 & 58. & 66.2 & 48. & 62.34 \\
\hline $\begin{array}{c}\text { Meeting } \\
1\end{array}$ & \multirow{5}{*}{ Cycle 2} & 67 & 69 & 58 & 70 & 51 & 63 \\
\hline $\begin{array}{c}\text { Meeting } \\
2\end{array}$ & & 69 & 70 & 58.4 & 69 & 50 & 63.28 \\
\hline $\begin{array}{c}\text { Meeting } \\
3\end{array}$ & & 72 & 71 & 63 & 69 & 53 & 66 \\
\hline $\begin{array}{c}\text { Meeting } \\
4\end{array}$ & & 74 & 73 & 65 & 70 & 56 & 68 \\
\hline Test & & 74.5 & 73.5 & 70 & 70.5 & 60 & 70 \\
\hline
\end{tabular}

From the table above, the students' average score from precycle stage to cycle II had significant improvement in which at precycle stage, the average score of students was 49.5. After giving some treatments by implementing picture word inductive model (PWIM) during more a month (conducted in two cycle), the students' average score improved. In cycle I, the students' test average score was 62.34. Considering the result gotten was not satisfied enough, the researcher continued it into second cycle. In cycle II, from 37 students, there were 34 students who passed the standard minimum of achievement, namely 70 with the average score of writing test was 70 . Therefore, it can be concluded that by implementing PWIM, the students' writing ability of descriptive paragraph improved. Besides, the students' mean score of creativity also increased in every meeting. The researcher guided the students by giving some questions related to the picture that used their imagination in answering them. The improvement of students' mean score of creativity can be seen in the table below:

\section{The Results of Students' Creativity in Writing at Precycle, Cycle I, and Cycle II}

\begin{tabular}{|c|c|c|}
\hline Meeting/ Cycle & $\begin{array}{c}\text { The Mean Score } \\
\text { of Students' } \\
\text { Creativity in } \\
\text { Writing }\end{array}$ \\
\hline \multicolumn{2}{|c|}{ Precycle } & 5.2 \\
\hline Cycle I & Meeting 1 & 5.2 \\
\hline
\end{tabular}




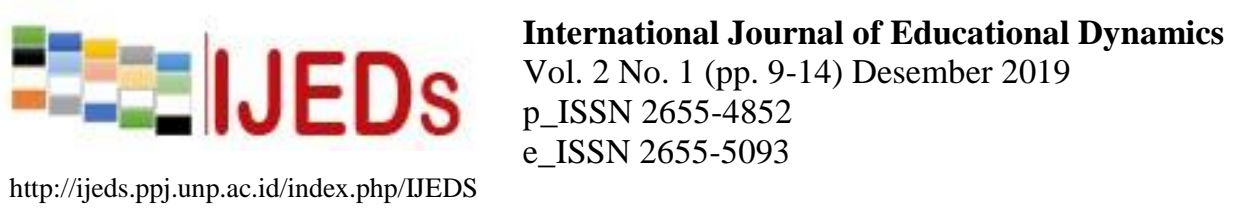

http://ijeds.ppj.unp.ac.id/index.php/IJEDS

\begin{tabular}{|c|c|c|}
\hline & Meeting 2 & 6.11 \\
\cline { 2 - 3 } & Meeting 3 & 6.42 \\
\cline { 2 - 2 } & Meeting 4 & 6.9 \\
& Test & 7.1 \\
\hline Meeting 1 & & 7.3 \\
\hline Meeting 2 & \multirow{3}{*}{ Cycle II } & 7.3 \\
Meeting 3 & 7.4 \\
Meeting 4 & & 7.3 \\
\hline Test & & 7.5 \\
\hline
\end{tabular}

From the table, it can be described that in the precycle stage, the students got low mean score of creativity. At this stage, there were many students categorized into low creativity. Moreover, in cyle I, the students' mean score had improvement per each meeting. The students' mean score at test in cycle I was 7.1. It was increased 1.9 points compared with precycle stage. However, in this cycle, there were many students who categorized into low creativity so that the researcher had to give more motivation and encouragement in order to decrease the number of the students who belonged to low creativity.

In cycle II, there was significant improvement in the mean score of the students' creativity. The mean score of the test showed 7.5 point. The improvement of students' creativity gave satisfied result in which from 37 students, there were 4 students who categorized into low creativity. It meant that the researcher stopped to do this research and did not continue to the next cycle because the researcher had found the improvement of students' writing ability of descriptive paragraph and their creativity in writing through PWIM.

Based on data analysis and findings of writing tasks and writing tests of descriptive paragraph, and also the creativity of the students in writing by implementing PWIM, it can be concluded that PWIM can improve students'writing ability f descritive paragraph and their creativity in writing at the second semester of non-English Department Students of UIN Raden Fatah Palembang.

\section{CONCLUSION}

\section{a. Conclusion}

The used of PWIM improved the students' writing on descriptive paragraph. The improvement can be seen in the average score of the students writing on descriptive paragraph. It was 62.34 in cycle 1 and 70 in cycle 2 . So, it inreased 7.66 point. In 


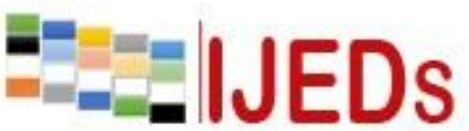

http://ijeds.ppj.unp.ac.id/index.php/IJEDS
International Journal of Educational Dynamics

Vol. 2 No. 1 (pp. 9-14) Desember 2019

p_ISSN 2655-4852

e_ISSN 2655-5093

addition, the use of PWIM also improved the students' writing ability in writing descriptive paragraph. The improvement can be seen in the total score of the students' creativity on descriptive paragraph. It was 263 in cycle 1 and 276 in cycle 2 . So, it inreased 13 point.

\section{b. Implication}

In line with the result of the research, there are several implications for the next teaching and learning process. Picture Word Inductive Model can improve students' writing ability and students' creativity as well at Non-English Department Students of UIN Raden Fatah Palembang. The Eglish lecturer can use this strategy in teaching writing.

\section{c. Suggestion}

The researcher gave some suggestions in this research. First, English lecturers who either teach in English Faculty or not and have problems dealing with their students' writing ability are suggested to use PWIM as a teaching strategy. English lecturers who have problems dealing with the students' creativity in writing are suggested to use PWIM as a teaching strategy too.The students are suggested to use PWIM as a learning strategy for improving their writing ability. The future researchers are recommended to conduct relevant research related to PWIM strategy in writing ability.

\section{REFERENCES}

Anas, Sudjono. 2006. Pengantar Statistik Pendidikan. Jakarta: PT Grafindo Pustaka.

Batstone, Rob. 1994. Grammar Language Teaching : A Scheme for Teacher Education. Singapore: Oxford University Press.

Bright, Robin. 2007. Write Through The Grade. Canada: Portage and Main Press.

Calhoun, Emily F. 1999. Teaching Beginning Reading and Writing With The Picture Word Inductive Model. Alexandria: ASCD.

Brookhart, Susan M. 2010. How To Assess Higher-Order Thinking Skills In Your Classroom. Alexandria: ASCD

Carroll, Robert Todd. 1990. Student Success Guide. United States: International Copyright Law.

Crusan, Deborah. 2013. Assessment in The Second Language Writing Classroom. USA: United of Michigan

Franken, R.E. 1994. Human Motivation. Retrieved from:www.csun.edu.

Hausman, Carl R. And Albert Rothenberg. 1996. The Creativity Question. Durham: Duke University Press. 
http://ijeds.ppj.unp.ac.id/index.php/IJEDS

IRMA. 2015. Curriculum Design and Classroom Management: Concepts, Methodologies, Tools, and Applications. Pennsylvania: IGI Global.

Janzen, E. Fletcher and Reynold, Cecil R. 2007. Encyclopedia of Special Education. New Jersey: John Willey \& Sons, Inc.

Joyce, B., Well, M., and Calhoun, E. 2013. Models of Teaching. Boston: Pearson.

Kinneavy, James L. 1992. A Rhetoric of Doing Essays on Written Discourse. USA: Board of Trustees.

Lambirth, A., Grainger, T., Goouch, K. 2005. Creativity and Writing: Developing Voice and Verve In The Classroom. New York: Routledge.

Mahler, Brenda and Caswell, Roger. 2004. Strategies For Teaching Writing. Alexandria: ASCD.

Nunan, David. 2003. Practical English Language Teaching. New York: Hill Companies Inc

Sarada, M. 2005. The Complete Guide to Resume Writing. New Delhi: Sterling Publisher.

Sepyanda, Marsika. 2013. The Effect Of PWIM And Students' Self-Efficacy Toward Their Writing Skill Of Descriptive Text At Grade X Of SMAN 1 IX Koto Sungai Lasi. (ejournal.unp.ac.id)

Tan, Al-girl. 2007. Creativity A handbook for teacher. Singapore: World Scientific Publishing. 